https://doi.org/10.29013/EJLL-19-4-10-13

Kauza Iryna,

Post-graduate student of

National University "Lviv Polytechnic"

E-mail:irynakauza1989@gmail.com

\title{
THOUGHT IN THOUGHT AS A DOMAIN OF TEXT INTERFERENCE
}

Abstract. Interference encompasses not only speech (for example, the direct speech of characters is always transmitted within the narrator's narrative), but also the discourse zones of the narrator and the character as a whole, that is, the various interactions of their assessments, perceptions, points of view, thoughts, experiences are conveyed by narrative means. It is assumed that the discourse zone of the narrator is formed directly during the narrative act, and the discourse zones of the characters exist before it (within the fictional world) and are only reproduced.

Keywords: interference, discourse zones of the narrator and the character, Thought in Thought.

The spread of text interference in the Englishlanguage works of postmodernism is associated with increased personalization of the narrative, with the increasing shift of perspective from the narratological pole to the personal. Personalization implies not only introspection of the narrator in the mind of the character (which, of course, is not excluded in the narrator's discourse), but also the transfer of the personal point of view to the level of the narrator, above all, in terms of perception. Thus, personalization sometimes gives the impression that the narrator is coming off the stage, giving his narrative competence to the character.

Such an idea of the disappearance of the narrator underlies many models of free-indirect speech from Sh. Balli to A. Banfield and E. Paducheva. The replacement of the narrator by the character is also discussed by the modeling of the distribution of functions in Dolezhel, which provides the possibility of transferring the characteristic for the narrator of the "image" (representation) and "control" functions on the character. But contrary to all theories, which presuppose the disappearance of the narrator or his replacement by the character, the analysis of Margarette Drabble's works gives us the opportunity to assert that the narrator, in the most objective expres- sion of the free-indirect speech, which Thought in Thought undoubtedly contains, remains "on stage".

In general, the narrative point of view is a way of expression by which the omniscient author is removed, and events are conveyed through the vision and perception of one character, who is called a reflector [7, 215-217]. But unlike a narration, where from the beginning to the end of a work within its architectonics one stylistically labeled non-identical epic plan is realized, a non-authorial narrative (with extensive use of Thought in Thought) is a peculiar combination of two or even more epic plans - a narrator and characters. Thought in Thought allows the author to portray events "internally", i.e. from the inside, in terms of their direct participant and "externally", from the side of the all-knowing author [6, 110-114].

Text interference arises from the fact that in the same passage of the text, some features show a relation to the discourse zone of the narrator, others - to the discourse zone of the character. Simultaneous relation to two zones creates the effect of coexistence and correlation of these zones [2, 243].

Considering the degree of interaction between subjective and authorial perspectives in M. Drabble's novels, we have identified several subtypes of 
Thought in Thought. First, it is the "classic" Thought in Thought, in which the narrator is deliberately removed from the narrative. For instance:

'If I were on my deathbed, it would be all the same to you lot. What do you care? I work my fingers to the bone, and what do you care? If I were on my deathbed, you wouldn't care. If I dropped dead, you'd walk over my dead body.'

And Clara, telling herself that she had heard these phrases, word for word, a hundred times before, and that hardly a mother in the world had not been driven to them, could nevertheless restrain a kind of thick shivering, for she knew, then, that her mother knew, and was thus obliquently imparting her terror and her information. For she too was not after all lacking in circumspection: she too could multiply implications. And knowledge lay between them, dourly, without comfort, inarticulate [9].

The transition from the narrator's thoughts to the character's Thought in Thought is marked by a pronoun transposition from the sphere of the third person singular into the sphere of the first person singular, change of the temporal plan of the story from Past Indefinite to Present Indefinite, choice of vocabulary - emotionally colored words and words of neutralized tone.

Secondly, there is a less long Thought in Thought in which the narrator and character participate in the information presentation on equal rights, interact closely and periodically change each other. For example:

And Clara's first thought, upon seeing him, was that he had known she was there, for he did not seemed surprised to see her: he could well have known it, for the evening had been arranged some days ago, and she knew that all the family were in daily contact; they would ring each other constantly, all over the country, at vast expense. It seemed dangerous to assume that he might have wished to see her; it seemed to be a notion that verged on madness, as so many of her notions in the past have done, or if not upon madness, then upon some colossal, crazy, optimistic hope. And yet other hopes just as crazy had in the past been fulfilled, so why not this one? [9]
In the above mentioned fraction of M. Drabble's novel we observe the identification of the thoughts and experiences of the character and narrator, who assimilates himself with the character, maintaining his point of view and perception and evaluation of the situation in general.

In the third case, Thought in Thought is inseparable from narrator's speech. The main narrator is the narrator, and the character can only occasionally insert his own word, using the narration method. For instance:

Clara, staring, in the instant before her mother stirred and woke, wondered how she could not have known, how she could have missed the warnings of this imminent decay. And she felt that she was standing empty-handed, bringing nothing, unless; in a jug by the bedside a few roses withered, and she thought, at least I could have brought her flowers. And she was the more ashamed because she had thought of bringing flower, she had passed, on the way there, a dozen flowershops, and had not stopped, because she had been afraid, afraid of rejection, afraid of that sour smile with which so many years ago her mother had received her small offerings of needle cases and cross-stitch pin cushions and laboriously gummed and assembled calendars. She had been afraid of the gesture; she had learned nothing, she could not give, and yet she knew that without gestures there was no hope that love might fill the empty frames, the extended arms, the social kisses, the proffered flowers. She had brought nothing, and her meanness dismayed her. She had not wished to be mean [9].

Reliance on personal discourse while maintaining the subject-modal plan of the narrator creates the effect of the reliability of the described, by enhancing the emotional impact on the reader, psychologizes and deepens the narrative, while complicating its structure, providing its polyphonic, limiting the ability to distinguish the author's point of view and evaluations. However, the need to differentiate between the speech-thinking segments of the characters of the work and the narrator is very important, because the content of the literary image cannot 
be correctly understood unless the boundaries between the narrator's and the character's judgments are drawn.

Otherwise, the reader will put the responsibility for making false statements and recommendations on the writer. In polyphonic novels, endowed with deep psychology, the isolation of Thought in Thought is a true domain of textual interference, closely intertwining and at the same time delimiting the epic plans of the narrator and the characters. In the course of Thought in Thought analysis in the sphere of text interference, we have distinguished the following features that made it possible to clearly distinguish between personal and narrative discourse:

1) Thematic features of Thought in Thought the narrator and character zones differ in the selection of thematic units and by characteristic themes;

2) The evaluative (ideological) features of Thought in Thought - discourse zones differ in the assessment of individual thematic units and in their semantic position in general;

3) The grammatical features of the person in Thought in Thought - discourse zones differ in the use of the personal pronouns and verbs, in particular modal verbs (in personal discourse their use is much greater);

4) grammatical signs of the verb's tense in contextualized fragments of Thought in Thought - in the character's text all three tenses are possible, in the narrator's text, as a rule, only the past (only in comments, readings, etc., the narrator can use all three tenses);

5) signs of pointing systems of Thought in Thought - the character uses the instructions such as "yesterday", "today", "tomorrow", "here", "there", and the narrator-type "that day", "one day ago", "this month" etc.;

6) signs of the linguistic function of segments of text with Thought in Thought - discourse zones of the character and narrator are characterized by different functions of the language - representative, expressive or appellative;
7) lexical features of Thought in Thought zones differ in different names of the same object or different lexical layers as a whole, whereby the discourse of the narrator is not necessarily interpreted in a book or neutral style and the discourse of the character is spoken and emphatic. For example, modal adverbs "certainly", "probably", "surely", "perhaps", "maybe", "obviously" predominate in contextualized fragments of the Thought in Thought of the discourse zone of the narrator, and adjectives and adverbs ("luckily", "fortunately", " regrettably, "merrily", "benignly", "irrelevantly", "ironically", "doubtfully"), which convey different axiological shades of states, predominate in the verbalized fragments of Thought in Thought of characters.

The peculiarity of the narrative discourse of the communicative space of M. Drabble's novels is the contaminated nature of the narrative structure, the lack of clear boundaries between the discourse strategies of the narrator and the characters, because not all signs are equally consecutively contrasting the discourse zones of the narrator and the character - on the contrary, many of them can be exactly the same or neutralized (hardly ever on may state who exactly (the character or narrator) Thought in Thought belongs to in a particular case, thus, the discourse zones of the narrator and character in this case merge). For example,

She knew them all, all the right phrases, but some deeply excluded modesty prevented her from using them. And she liked the way they talked about poetry and about poetry readings, and audiences, and whether people understood it or not, and whether people liked it or not, and whether people who went to poetry readings liked whatever they heard anyway, simply because they were the kind of people who liked going to poetry readings and hearing poetry: and she could tell from the tone and the pattern of the talk that everyone there had expressed similar views in similar conversations a dozen times before, but was nonetheless ready to express them once more, for all that: and it was this sense of trivial, 
gossipy familiarity and repetition that most pleased her, for it convinced her that she was listening to real professionals [9].

The concept of text interference implies that the discourse zone of the character in the discourse zone of the narrator is somehow processed. Between the pure language of the narrator and the pure language of the character there is a wide range of mixed forms, that is, transformations of the character think- ing with different distribution of characters in the speech of the narrator and the character thinking.

Thus, Thought in Thought in the sphere of text interference is an excerpt, fragment of narrative text that conveys thoughts, feelings, perceptions, or only the semantic position of one of the portrayed characters, whereby the transmission of the character's discourse zone is not marked with either graphic characters or words (or their equivalent).

\section{References:}

1. Bakhtin M. Statement as a dumb boyfriend / Mikhail Bakhtin // Anthology of science and critics of the twentieth century. [ed. M. Zubrytskaya].- Lviv: Litit, 2001.- P. 406-415.

2. Dryeva D. M. Means that I populate the expression in text messages on poetic discourse. Scientific vector of the State University of Togliatti, 2 (36), 2016.- P. 242-246.

3. Valentine Lee. On the subject of anthropocentric paradigm in contemporary linguistics. URL: http://gisap.eu/en/node/83000

4. Selivanova E.A. Fundamentals of the Linguistic Theory of Text and Communication / E.A. A. Selivanov - Kiev: Brama, Izd. Vovchok O. Yu., 2004.- 336 p.

5. Pascal R. Double voice: free indirect speech and its functioning in the European novel of the nineteenth century.- Manchester: Manchester University Press. 1977. - 290 p.

6. Bekhta I. A. The author's expedition in the $20^{\text {th }}$ century English prose / Ivan Bekhta.- Lviv: PAIS, 2013.$268 \mathrm{p}$.

7. Bekhta I.A. Discourse of the Speaker in English Prose.- Kiev: Diploma, 2004.- 304 p.

8. Artsyshevskaya A. L. Linguopragmatic typology of the representative component in molding reproduction systems [Text]: author's abstract. dis ... Candidate filol Sciences: 10.02.04 / Artytsevskaya Anetta Leonidivna; - Lviv. nats Un-t them. I. Franko - Lviv, 2001.- 20 p.

9. Drabble M. Jerusalem the Golden (electronic book). 